\title{
BUREAUCRATIC PATHOLOGY IN E-KTP AND KK SERVICES IN DEPARTMENT OF POPULATION AND CIVIL REGISTRATION OF NORTH CENTRAL TIMOR REGENCY
}

\author{
Tameon Y.*, Djani W., Neolaka M.N.B.C. \\ Master Program in Administration Science, Graduate Program, \\ University of Nusa Cendana Kupang, East Nusa Tenggara, Indonesia \\ *E-mail: cephergralat@yahoo.com
}

\begin{abstract}
This research aims to analyze e-KTP and KK services in Department of Population and Civil Registration of North Central Timor Regency; describe the bureaucratic pathology in e-KTP and KK services in Department of Population and Civil Registration of North Central Timor Regency; and examine aspects affecting bureaucratic pathology in e-KTP and KK services in Department of Population and Civil Registration of North Central Timor Regency. This research focuses on pathology due to lack of knowledge and skills; pathology manifested in bureaucratic behavior; and pathology as a result of the situation in the governmental environment. This research used qualitative method with qualitative descriptive research approach. The research was conducted in Department of Population and Civil Registration of North Central Timor Regency. In determining the informants, the researchers used the purposive technique. Data collection techniques used in this study was unstructured interviews, documentation, and observation. The data analysis was divided into four major activities: data collection; data condensation; data display, and conclusion/verification. The results of the study show that bureaucratic pathology in e-KTP and KK services in Department of Population and Civil Registration of North Central Timor Regency are due to low ability and skill of the officials, poor bureaucratic behavior with arbitrary and discriminatory actions, particular situation in the government, the excessive procedure, the pressure from the applicant to the officials to complete the required documents, conspiracy relationship of a group of people, rigid attitude in interaction, aloofness to the quality of performance, negligence of duty by the officials, and family interests prioritization over the public interest.
\end{abstract}

\section{KEY WORDS}

Pathology, bureaucracy, bureaucratic pathology, services.

The issue of public services basically covers the vast aspects of life. The government has the function of providing various public services needed by the community, ranging from arrangements services to fulfillment services in various areas of life. The various public reform movements experienced by developed countries in the early 1990s were much inspired by public pressure on the need to improve the quality of public services provided by the government.

Indonesian citizens consider the bureaucratic conditions in Indonesia are unsatisfying. Therefore, future development should be put to avoid the impression that the government is ineffective, slow, not creative, less responsive, and less sensitive to the public. This has led to the crisis of trust in the government within the framework of the bureaucratic politics strengthening directed at bureaucratic reform. Bureaucracy must be built in the context of development because bureaucracy must be able to be a reliable development instrument. In recent developments, complaints and criticisms about the performance of the bureaucracy are not new anymore. Bureaucracy shows more empirical conditions which are considered very terrible, negative, or as a disease (bureaupathology).

Government agencies at various levels should focus on providing services to the people as the target of services. If the government and supporting institutions expect maximum service from the public, they will have to give the best service. The government is actually obliged to give twice maximum service if they realize that the services provided are 
not solely due to moral responsibility to imply an effort of repayment or normal action to meet the elements of consensus in the constitution, but rather as a mandate from the service provider (Labolo, 2013: 54).

Accordingly, the phrase which states that the presence of the State Civil Apparatus is to serve and not to be served should be realized in the daily practice of the state administration. When it does not exist, the phrase only becomes a slogan without meaning. This is because the main task of the government is essentially to provide public services in order to improve the welfare of the community. One of the bureaucratic works can be seen from the cooperation between Department of Population and Civil Registration with the District Government in issuing identity card and family card. In this case, the Department as the implementing element of Regional Government of North Central Timor Regency is a bureaucratic institution that has duties in KTP (National Identity Card, Kartu Tanda Penduduk) and KK (Family Card, Kartu Keluarga) services such as registration, data recording, and issuance of KTP and KK. The procedures for making or renewing KTP and the issuance of KK include the applicants fill in the application, bring the covering letter from the RT, bring validation letter from the Village Head and Sub-District Head, and then visit the District Head Office to conduct population data recording. Finally, KTP and KK are issued by Department of Population and Civil Registration.

Through established procedures and complete requirements, a resident is entitled to have KTP and KK easily. In reality, there are still many residents who have been through official procedures and meet the requirements but they have not received KTP and KK. The possible reasons are the slow apparatus performance, the complicated process of KTP and KK management, and the lack of information given to the community regarding the requirements, time, and procedure in making the population documents.

Moreover, the related officials do not understand the given duties and responsibilities. For example, data from Kefamenanu Town district shows that there have been no problemsolving efforts for the residents that have been doing KTP data recording in Kefamenanu Town district since August $1^{\text {st }}, 2016$, until May $15^{\text {th }}, 2017$. Data still halts in the server of Kefamenanu Town district or has not been sent to the Master Server of Directorate General of Population at the Ministry of Home Affairs in Jakarta. This indicates that there is problem blurriness, fear in making decisions, and ignorance of criticism and suggestions.

\section{LITERATURE REVIEW}

Bureaucracy. According to Weber cited by Surie in Pasolang (2008: 9), the definition of bureaucracy is as a rational organization, the most important and ideal instrument of power in implementing efficient and effective governance. In other words, bureaucracy is a number of traits with relative importance relates to each other. The most striking features are the clearly defined areas of competence and the continuous execution of official duties. Furthermore, Blau's bureaucracy in Pasolang (2008: 7) is a type of organization designed to accomplish large-scale administrative tasks by coordinating the work of many people systematically. Meanwhile, according to Sinambela (2006: 70), the bureaucracy is an organization aimed at maximizing efficiency in administration.

Further, Sinambela states that the bureaucracy is characterized by: (1) specialization duties, (2) hierarchy of authority; (3) regulatory bodies; (4) reporting system; and (5) personnel with special skills and roles. Another opinion stated by Atmosudirdjo (1971) that bureaucracy has three meanings, i.e.: (1) Bureaucracy as a type of organization. As a particular type of organization, bureaucracy is suitable for carrying out and conducting works bound by routine rules, meaning that the volume of work is large but repetitive, and works that requires equitable and stable justice; (2) Bureaucracy as a system, which means a system of work based on the relationship of cooperation between positions (officials) directly and formally to the problem without favoritism or indiscriminately; (3) Bureaucracy as a working life. In this case, a rigid working life because of machine-like works, coupled with strict work discipline and obedience to mandate and regulations. 
Bureaucratic Pathology. Administrative disease or pathology can be interpreted as a condition where humans as the main element in administration have the main intention to cooperate not to meet the needs of the community, but to work together to meet the needs of individuals at the expense of others. Ndraha, Thoha, Blau, Osborne, and Schoorl define bureaucratic pathology as a disease, negative behavior, or irregularities committed by officials or bureaucratic institutions in order to serve the public, carry out tasks, and run development programs (Makmur, 2007: 63). Bureaucratic pathology (Bureaupathology) is the set of problems that arise from exaggerated bureaucratic controls. Thompson states that the features of bureaucratic pathology are "excessive aloofness, ritualistic attachment to routines and procedures, resistance to change, and petty insistence upon rights of authority and status".

In general, bureaucratic pathology is a disease in the state bureaucracy arising from the behavior of bureaucrats and the conditions that give the opportunities for it, whether political, economic, social, cultural, and technological. Furthermore, Siagian (1988) writes several bureaucratic pathologies that can be found, among others: (1) misuse of authority and responsibility; (2) problem blurriness; (3) indications of corruption, collusion and nepotism; (4) indication of maintaining the status quo; (5) empire building; (6) fear of change, innovation, and risk; (7) indifference to criticism and suggestions; (8) fear of making decisions; (9) lack of creativity and experimentation; (10) low credibility; (11) less imaginative vision; (12) lack of knowledge and skills, and others.

Furthermore, according to Siagian (1988), bureaucratic pathology can be grouped into five categories, i.e.: (1) Pathology arising from the perception and managerial style of bureaucrats; (2) Pathology caused by lack of knowledge and skills of bureaucratic executing officers; (3) Pathology arising from the actions of bureaucrats who violate the norms of law and legislation; (4) Pathology manifested in the behavior of dysfunctional bureaucrats; and (5) Pathology as the result of the situation in various analyzes within the governmental environment.

The scope of bureaucratic pathology using Smith's terminology with respect to poor bureaucratic performance can be mapped in two major concepts namely: (1) Dysfunctions of bureaucracy, which is related to structure, rules, and procedures or poor institutional bureaucracy and bureaucratic characteristics, so unable to realize good performance with good quality. (2) Maladministration, which is related to incapability or bribed behavior, including corrupt behavior, insensitive, arrogant, lack of information, ignorance, and bias, or closely related to the quality of human resources or bureaucrats in the bureaucracy.

Bureaucratic Ethics. Ethics, according to Bertens in Pasolong (2007: 190) is the habits, customs, or morals. From this definition, it can be concluded that ethical issues always relate to human habits or character (as individuals or in certain positions), either good habits or character or bad habits or character. Good character manifested in good behavior is often said to be something worthy or deserved, while the bad character which manifested in bad behavior is often regarded as something inappropriate or improper.

Within the scope of public services, public administration ethics by Pasolong (2007: 193 ) is defined as the philosophy and professional standards (code of ethics) or right rules of conduct (rules of correct behavior) which should be followed by public service or public administration officials. Thus, it can be concluded that the ethics of public administration are rules or standards of management as moral direction for members of the organization, management, and public administrators in carrying out their duty to serve the community. The rules or standards in the administrative ethics relate to staffing, supplies, finance, administration, and public relations.

The Concept of Public Service. According to Sinambela (2010), basically, every human need service. It can be said that service cannot be separated from human life. According to Kotlern (Lukman, 1997), service is any beneficial activity in a collection or unity and offers satisfaction even if the result is not bound to a product physically. Furthermore, Sampara argues that service is an activity that occurs in direct interaction between someone with another person or machine physically and provide customer satisfaction. 
Further, understanding of the concept of public service must be known. According to Moenir (1992), service is a series of activities because it is a process of direct service on a regular and continuous basis for the society. From the definition that has been described, it can be concluded that the quality of service is a series of processes covering the needs of the community served on an ongoing basis.

Public services tend to be a concept often used by many parties, both from practitioners and scientists with different meanings. In the history of public administration, public service was originally understood simply as a service organized by the government. All goods and services organized by the government are then referred to as public services (Dwiyanto, 2011: 14). The previous literature generally explains that "whatever government does is public service". Such opinion is understandable because the government at that time only cared to provide services that became public goods or services which according to a political agreement and moral considerations were considered important for the citizens. However, when there has been a change in the role of government and non-government in the services delivery in the current era, the definition of public service as mentioned above needs to be rethought.

According to Sinambela in Pasolang (2008: 211), the quality of excellence service is reflected from (1) Transparency, i.e. services that are open, easy, and accessible to all parties in need and are provided adequately and easily understood; (2) Accountability, i.e. services accounted for in accordance with the provisions of legislation; (3) Conditional, i.e. services in accordance with the conditions and capabilities of the provider and the beneficiary by keeping the principles of efficiency and effectiveness; (4) Participatory, i.e. services that can encourage community participation by taking into account the aspirations, needs, and expectations of the community; (5) Equality of rights, i.e. services that do not discriminate any aspect, especially tribe, religion, race, class, social status; (6) The balance of rights and obligations, i.e. services that consider the aspects of justice between the giver and the recipient of public services.

According to Zethaml and Farmer in Pasolang (2008: 211), there are three main characteristics of service, namely: (1) Intangibility; means that service is essentially performance and experience rather than an object. Most services cannot be calculated, measured, touched, or tested prior to delivery to ensure quality. It is different with the items produced by a factory that can be tested for quality before being delivered to the customer. (2) Heterogeneity; means the service user or client or customer has a very heterogeneous need. Customers with the same service may have different priorities. Similarly, performance often varies from procedure to procedure from time to time. (3) Inseparability; means that the production and consumption of a service are inseparable. One of the consequences in the service industry is the quality is not engineered into production in the factory sector and is delivered to customers. Quality occurs during interactions between clients and service providers.

\section{METHODS OF RESEARCH}

This research used the qualitative method with descriptive qualitative research approach. The focus and sub-focus of this research are:

Table 1 - Focus and Sub-Focus of the Research

\begin{tabular}{|c|l|l|}
\hline No & \multicolumn{1}{|c|}{ Focus } & \multicolumn{1}{|c|}{ Sub-Focus } \\
\hline 1. & Pathology due to lack of Knowledge and Skills. & $\begin{array}{l}\text { a. carelessness and incompetence. } \\
\text { b. unproductivity }\end{array}$ \\
\hline 2. & Pathology manifested in Bureaucratic Behavior. & $\begin{array}{l}\text { a. Arbitrary act } \\
\text { b. Discriminatory }\end{array}$ \\
\hline 3. & $\begin{array}{l}\text { Pathology as a result of the situation in the } \\
\text { governmental environment. }\end{array}$ & $\begin{array}{l}\text { a. Excessive workload } \\
\text { b. less conducive condition of the working environment. }\end{array}$ \\
\hline
\end{tabular}

This research was conducted at Department of Population and Civil Registration of North Central Timor Regency. In determining the informants, the researchers used the 
purposive technique or determination of informant with a certain consideration. Data collection techniques used in this study was unstructured interviews, documentation, and observation. The data analysis was divided into four major activities: (1) data collection (2) data condensation, (3) data display, and (4) conclusion/verification.

\section{RESULTS AND DISCUSSION}

Bureaucratic Pathology (Bureaupathology) is the set of problems that arise from exaggerated bureaucratic controls. Thompson states that the features of bureaucratic pathology are "excessive aloofness, ritualistic attachment to routines and procedures, resistance to change, and petty insistence upon rights of authority and status". Based on the results of research, bureaucratic pathology in Department of Population and Civil Registration of North Central Timor Regency occur due to:

First; pathology due to lack of knowledge and skills. Knowledge and skills are important aspects of a service. Education and skills support effective and efficient service. Carelessness and incompetence due to the low level of education and the lack of skills possessed by the Organization of Regional Devices can be found in e-KTP and KK services in Department of Population and Civil Registration of North Central Timor Regency. In addition, unproductivity becomes another factor due to limited knowledge and skills.

Second, pathology due to bureaucratic behavior. Pathology due to bureaucratic behavior in giving service with arbitrarily and discriminative actions is always found in every institution especially related to public service. Bureaucratic behavior in e-KTP and KK services in Department of Population and Civil Registration of North Central Timor Regency has no significant changes and is still covered by various irregularities and inefficiencies because the behavior of the apparatus does not change. The paradigm shift only reverberates as a political rhetoric at the symbolic level, not in its social practice.

Third, pathology due to the situation within the governmental environment. Many factors affect the performance of an institution in providing services to the community such as Human Resources, funds, facilities, and infrastructure. Especially for Department of Population and Civil Registration of North Central Timor Regency, many parties complain about the physical condition of the office. The physical condition of an office building used to provide public services does affect the performance of public services. Rapid and dynamic development of the organization of regional devices is an indication of very high activities, both internal activities and external activities of the organization. Department of Population and Civil Registration of North Central Timor Regency still has bureaucratic behavior by not optimizing the existing resources in order to maximize the applicant's service in completing the required documents. The department has not yet showed significant changes in order to realize a clean and good government.

In addition to the above findings, this research also found other aspects related to bureaucratic pathology. First, the excessive procedure. Established procedures in managing KK, e-KTP, and other residence documents should be applied openly and responsibly. In facts, the existing procedures have been ignored by the officials and by those who consider that the service process and service goals are not clear. This makes the applicants become confused because the procedure is excessive and seem artificial.

Second, pressure. The officials work as hard as possible in providing KK, e-KTP, and other documents services. However, some obstacles and limitations occur unintentionally, such as: running out of blank applications, peripheral computer interference or signal disturbance, and disturbance on server, either server in district, in department, or main server in Directorate General of Population in Jakarta. Some people can understand this condition, but some do not understand and force to be served by conveying their purpose smoothly, clearly, and easily to be understood and taking the empathy approach.

Third, conspiracy. Conspiracy is common among elites in bureaucracy with emotional closeness such as family, friends, acquaintances, or other relationships. It usually takes a very fast service or a short time service for those managing KK, e-KTP, birth certificate, and other documents without being noticed by others. It can also happen as a recompense of 
particular services for the bureaucrats, so the process can be completed without following the correct procedure.

Fourth, excessive indifference. Actually, the public assessment that the officials are indifferent in providing services that cause inaction is not fully justified. It is because many unknown factors affect the untimely service is in accordance with the existing SOP, such as lack of blank applications of KTP, KK, and Civil Register and slow data validation. Ministry of Home Affairs always limits the blank applications. For example, the Department requested 10,000 blank applications of KTP, but only 4,000 blanks were served. Similarly, the data validity from the Directorate General of Population at the Ministry of Home Affairs, in which the applicants perform concurrent recording, might not be completed simultaneously. Some takes months, even years.

Fifth, rigid attitude. People who need e-KTP and KK services are often rigid with what the officials instruct, let alone to meet with counter officials, operators, and other officials. The rigidity can hamper the process of KTP, KK, and other affairs because they do not understand what is being delivered. Even, they are rigid with the rules and consider that the requirements seem to be contrived by the officials. While in fact, the bureaucrat apparatus in the department are not rigid in providing services. They have to refer to and follow the rules that govern their duties because they could be perceived to be in rules violation once they break the rules.

Sixth, aloofness to the quality of performance. The quality of performance at Department of Population and Civil Registration of North Central Timor Regency has not shown effectiveness in the service process as expected by the community. This is because the placement of an employee or official is not in accordance with the field or specification of his/her expertise. The officials need time to adjust, while the community needs services to be constantly running. Sometimes, there are technical errors in writing accidentally done by the officials as well. However, in general, the work of this department can be measured from the document of the population printed and published every day.

Seventh, negligence of duty. Outgoing duties for the officials responsible for the process of KTP recording and KTP and KK printing enlarge the document file accumulation because there are several vacant positions. The society considers this as the negligence of duties. For example, the officials ask the applicants to come again in one or two more days, the officials is not in place, run out of the blank applications, signal disturbance and computer equipment disrupted, and so forth. So, it seems that the officials neglect the task and are not responsible for the obstacles faced by the department.

Eighth, intricate service. Some people confessed that they need several times to manage KTP in Department of Population and Civil Registration of North Central Timor Regency and in the sub-district office. The process for getting one piece of KTP is very long and complicated. After the data is recorded in the district, the data is sent to Jakarta to be validated, then being sent back to be printed by the department. The applicants must complete a number of documents that seem to be intricate. In addition, some obstacles occur in the department such as run out of the blank applications, engine error, power outages, or the officer is not in place.

Ninth, family interests prioritization. People with family relation always have prioritization in KK and e-KTP services. This leads to a preferential service process. The term is usually called as an insider. Someone with an insider will have quick process, while some without an insider will have to wait for months.

\section{CONCLUSION}

Based on the analysis of research result and discussion related to bureaucratic pathology on e-KTP and KK services in Department of Population and Civil Registration of North Central Timor Regency, it can be concluded that: (1) pathology due to low ability and skill of the officials, (2) pathology due to low bureaucratic behavior with arbitrary and discriminatory actions, (3) pathology due to the situation within the governmental environment, (4) the excessive procedure, (5) the pressure from the applicant to the officials 
to complete the required documents, (6) pathology due to conspiracy relationship of a group of people, (7) pathology due to rigid attitude in interaction, (8) pathology due to aloofness to the quality of performance, (9) pathology due to the negligence of duty by the officials, (10) pathology due to an intricate service, (11) pathology due to family interests prioritization over the public interest, (12) and several aspects that cause bureaucratic pathology including employee recruitment, employee selection, training, awards, and assessment.

Based on the research result and conclusions, some recommendations and suggestions can be made, i.e.: (1) knowledge and skills improvement through education and training and formal education for Human Resource development in the department in order to provide careful and skillful services to the applicants, (2) avoidance of arbitrary and discriminatory actions both internally and externally for the applicants in the population documents process, (3) the environment improvement to create a safe, comfortable, and conducive atmosphere for the officials and the applicants, (4) avoidance of conspiracy action, the public interest prioritization, and fair and equitable service to all applicants, (5) avoidance of the negligence of duty and professionalism prioritization in providing services to the applicants, and (6) correct and appropriate implementation of employee recruitment, employee selection, training, rewards and job performance appraisals to provide more effective and efficient service.

\section{REFERENCES}

1. Ahmad, F. (1992). Untaian Pemikiran Tentang Administrasi dan Pembangunan. Malang: Lembaga Penerbitan dan Publikasi Fakultas IImu Administrasi Universitas Brawijaya Malang.

2. Albrow, M. (1996). Birokrasi. Translated by R. Karim. Yogyakarta: PT. Tiara Wacana.

3. Labolo, M. (2013). Memahami Ilmu Pemerintahan Suatu kajian, Teori, Konsep dan PengembangannyA. Jakarta: PT. Raja Grafindo Persada.

4. Makmur. (2007). Patologi Serta Terapinya dalam Ilmu Administrasi dan Organisasi. Bandung: T. Refika Aditama.

5. Pasolong, H. (2011). Teori Administrasi Publik. Bandung: Alfabeta.

6. Pasolong, H. (2008). Kepemimpinan Birokrasi. Bandung: Alfabeta.

7. Sinambela, L. P. (2006). Reformasi Pelayanan Publik: Teori, Kebijakan, dan Implementasi. Jakarta: Bumi Aksara.

8. Siagian, S. P. (1988). Patologi Birokrasi Analisis Identifikasi dan Terapinya. Jakarta: Ghalia Indonesia. 